\title{
Editorial Trust and transparency
}

INCE THE call for papers to the theme for this issue of the Pacific Journalism Review, more tumultuous events in journalism have unfolded dominated by the agonising restructure of the newspaper arms of media companies across the region. Hundreds of editorial jobs are on the line. The increasingly desperate search for the 'new business model' has been stepped up. But is the new model the only answer to the current plight of journalism? Are media proprietors paying enough attention to the fact that the business model is built on the public trusting the journalistic practices that sit at the heart of the media brands? Perhaps all stakeholders should pay closer attention to Conboy's thoughts?

...this doom-laden perspective, which permeates the news media industries ignores the fact that historically it is the audience, not the business model, which defines the contours of journalism. The business model has simply enabled journalism to marketise this audience for maximum profitability. (Conboy, 2010, p. 7)

From this perspective to retain public trust in journalism and to rebuild lost trust becomes as important as the quest to make online journalism pay. Indeed, without, or with low, public trust in news media, will online journalism ever pay enough to sustain quality journalism?

One important tool to retain and rebuild trust in any professional practice is openness and accountability. It is to achieve this that industries construct ethical codes of conduct to complement the existing legal frameworks. Journalism and the news media companies have, in a long struggle during the last century, convinced other societal powers that it must be allowed to self-regulate (or employ variations of self-regulation such as co-regulation). This is to be able to fulfil its most important task: hold those that exercise power in society accountable for their actions.

Self-regulation is built on trust. What happens when the trust is not honoured? This eventuated in the News of the World debacle in the UK so eloquently captured by the Moir cartoon on the cover of this issue and the opposite page. Or in the words of the Lord Justice at the opening of the Leveson 


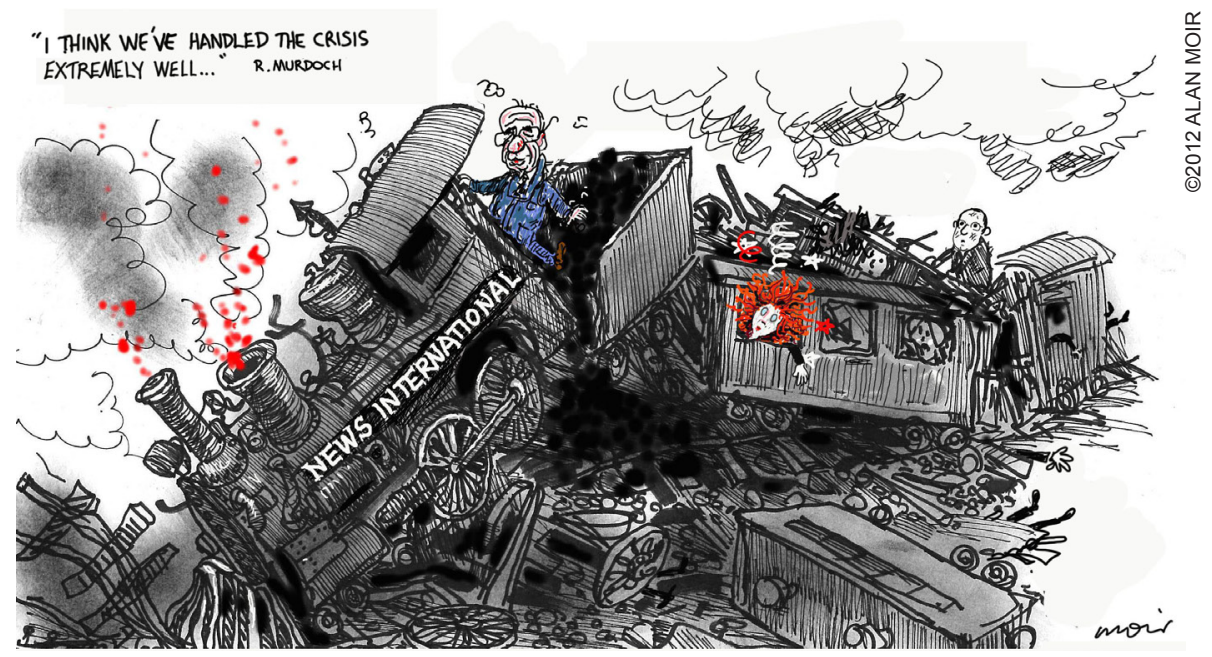

inquiry: 'Who guards the guardians?'(Leveson, 2011). Variations of this question have been asked many times, but never before in such dire circumstances.

The Australian versions of the Leveson Inquiry, the Independent Media Inquiry (IMI) (Finkelstein, 2011) and the Convergence Review (Boreham, 2012), have now both reported. The former provoked much debate regarding its suggestion to create an independent government funded, statutory-based News Media Council to hear complaints across all platforms. The Convergence Review produced a far less prescriptive document that seeks to engage the industry in shaping the future media regulation system in Australia.

What became clear in mainstream media's coverage of the reports is that debate and discussion often gets stuck on the regulation issue and seldom deals with the core of the problem - public trust in and accountability for its practices.

In New Zealand, the debate has been relatively muted about public trust in the media in spite of a NZ Law Commission discussion paper last December which made far-reaching recommendations on 'digital media age regulation'. The commission's preferred solution is a new single regulator created by statute to which all complaints about 'news media' would be directed. Unlike the self-regulated Press Council or the statutory Broadcasting Standards Authority (BSA), the new regulator could intervene without any complaint being laid and - possibly - even before a story is published where there are concerns about the methods the journalist used to gather information. The commission 
recommends an 'independent panel' to appoint members of the new body, with the majority being from outside the industry. But public discussion has been more directed towards the Australian and British developments.

Now everyone is waiting for Leveson to report. Sometimes it feels like the Samuel Beckett play Waiting for Godot. This time, however, Godot will arrive. The submissions and hearings in the inquiry have laid bare a culture of journalistic misconduct that reaches far into the British establishment. These malpractices are the most blatant betrayals of trust, a breach of the social contract for journalism, in recent times. Because of the severity of the breaches, the importance of the Leveson report and its impact outside Britain will be significant.

The themed section of PJR engages with a range of issues directly or closely connected to public trust and media accountability:

Duncan Bloy reflects in the first of four commentaries on missed opportunities in the Leveson inquiry, what impact it may have on journalism in the UK and elsewhere and what sort of regulatory model the Leveson report may recommend. Wendy Bacon provides one of few summaries that dealt with the substance of the Independent Media Inquiry Report, rather than singling out the one aspect of it. Her article was originally published in the alternative online news and current affairs publication New Matilda.

Rod Tiffen advised the IMI and was on the receiving end of some of the reactions by the industry and other commentators after the report was published. This piece, originally published in the The Sydney Morning Herald, is his response. Dennis Cryle explores the influence and reach of News Limited's flagship-The Australian, how the different editors have shaped the paper and its reaction to the IMI report. In New Zealand, while the debate has been far more muted than in Australia and the UK, changes are also happening, as Linda Clark outlines: 'While there is no such political urgency to regulate the media the commission is likely to stick to its guns and recommend streamlining and strengthening.'

In the first of six research articles, Paul K. Jones foresees that the Leveson inquiry will be a watershed moment in multi-platform media regulation. Jones questions the neo-liberal orthodoxy that digital convergence would mean the expansion of the current newspaper self-regulatory model into other media formats and weighs up the Australian inquiries in the light of history and "first amendment fundamentalism'. 
Johan Lidberg argues, based on a content analysis, that close to all media proprietors that made submissions to the two Australian inquiries squandered the opportunity to seriously engage in discussing issues of public trust and the importance of media accountability. Mark Pearson suggests that there already is enough regulation in Australia and that content is better regulated and publishers held to account by drawing on and slightly amending existing consumer and privacy laws.

Patrizia Furlan examines matters of life and death - the trust relationship between medical reporters and PR practitioners representing the pharmaceutical industry. Most of the time the public/audience is unaware of this relationship.

Gavin Ellis provides a comparative overview of ethical codes using a sample from the Anglo-American press and countries and argues that the codes will endure and change little as they are still relevant and have developed over a long time. The issue at hand is to how to implement and police the codes in an effective way. Jared Obuya explores the fledgling steps of the Kenyan press council and finds good intentions hampered by a poorly funded body dominated by a few big media houses. A situation that is uncomfortably similar to the old version of the Australian Press Council.

There is a common thread to be found in all articles and commentaries in the themed issue - the issue of public trust and accountability in news media practices is not only vital for the future of the industry, but a necessity for the health of democratic systems. If the legal and ethical transgressions in some of the News International publications in the UK leads to a global serious discussion, including the media owners, regarding these issues, then something good will have come out of one of the biggest scandals in modern journalistic history.

\section{Dr Johan Lidberg}

School of Journalism

Australian and Indigenous Studies

Monash University

arts.monash.edu.au/journalism/ 
T FIJI, where the regime authorities are preparing for the first elections In eight years in 2014, a generally dismal post-censorship mediascape was brightened in mid-September by a courageous new publishing upstart. Repúblika has pledged to win back the credibility and public trust of the local Fiji media. 'This is our time to build the nation we envision,' wrote editor Ricardo Morris in the monthly's first edition editorial, branded the Repúblika Manifesto. 'But for us to do this we should be unafraid to emerge from the shadows into the national conscience, to raise our voices against injustice and prejudice.' He highlighted the challenge facing the media:

Like no other Pacific country, Fiji has been fated with a unique amalgam of ethnicities, with the iTaukei-the [indigenous] Fijian' in pre-2006 parlance - as the first peoples of this archipelago. But rather than be a cause of division, Fiji's rainbow of ethnicities should be the centrepiece of a country whose peoples can put aside prejudices and bigotry and construct a free and just nation ...

We aim to regain some of the vibrancy of a free media, to act as a mirror on society without fear or favour. The Pacific — and Fiji— has not been immune to the ethical lapses that have been all too common in recent years in media establishments around the world so we anticipate being held to the same high standards we expect of our leaders and those we criticise.

The only unthemed article in this edition deals with the so-called Fiji 'coup culture'. Written by a former Fiji Daily Post publisher, Thakur Ranjit Singh, it makes the case that Fiji never really enjoyed genuine democracy after independence from Britain in 1970. It analyses media perceptions in the light of this history of Fiji.

In the May edition of $P J R$, we launched an innovative From The Frontline section of the journal devoted to investigative journalism as a research methodology. We published two Asia-Pacific case studies - both in the minerals sector and by postgraduate student journalists - as examples of this initiative. One was an inquiry into the Freeport gold and copper mine in the Indonesianruled region of West Papua and how, plagued by human rights allegations for four decades, the US-owned company had apparently compromised the 'ethical' investment policy of the NZ Superannuation Fund. This was written by Karen Abplanalp (2012) for Metro Magazine. The other investigation was written by New Caledonian-born Nicole Gooch (2012) who did a comprehensive 
report on the Brazilian-owned Vale New Caledonia nickel smelter at Goro in the south-east of the Pacific territory. A shorter version of this was published in the Global Mail.

In this edition, our newly appointed Frontline editor, Professor Wendy Bacon, long an advocate of investigative and long-form journalism as a serious research genre in the academe, writes a commentary about the strategy and she calls for contributions in future editions. Frontline articles will be distinguished by their investigative format and an academic exegesis which provides the context and methodological rationale. As she writes:

[F]or the time being at least, the ground ha[s] shifted to provide new opportunities for innovation and research-based journalism in the academy. In practice, the levels of acceptance of this new opportunity by both journalism academics and assessors have differed between countries, institutions and individual academics. In the first and second rounds of the Excellence in Research for Australia (ERA) evaluation, a number of universities have put forward works of journalism practice, each accompanied by short statements explaining the significance of the contribution of the research to knowledge and the methodologies and approach use.

The situation remains fluid, however, as some senior journalism academics give little encouragement to practice-based research while other institutions are still nervous or reluctant to put forward unconventional research. (Bacon, 2012, pp. 157-8)

This new PJR section provides an opportunity to explore possibilities of journalism as research in ways that might not only increase our value to universities as researchers, but would also enhance the broader field of journalism.

In the next edition of PJR, the theme will be Media Democracy in the South Pacific with a mix of papers drawn from a recent conference of that name at the University of the South Pacific and a wide range of other submissions from the region.

\section{Professor David Robie}

Pacific Media Centre

AUT University

www.pmc.aut.ac.nz 


\section{REBUILDING PUBLIC TRUST}

\section{References}

Abplanalp, K. (2012). 'Blood money': A NZ investigative journalism case study. Pacific Journalism Review, 18(1), 128-147.

Bacon, W. (2012). An innovative direction in academic journalism. Pacific Journalism Review, 18(2), 153-165.

Boreham, G. (2012). Report of the Convergence Review. Canberra: Department of Broadband, Communications and the Digital Community, Australian Federal Government. Available at www.dbcde.gov.au/digital_economy/independent_ media_inquiry

Conboy, M. (2010). The paradoxes of journalism history. Australian Journalism Review, 32(1), 5-13

Finkelstein, R. (2011). Report of the independent inquiry into the media and media regulation. Canberra: Department of Broadband, Communications and the Digital Community, Australian Federal Government. Available at www.dbcde.gov.au/ digital_economy/independent_media_inquiry

Gooch, N. (2012). Background to 'Sulphate sunrise' —investigating New Caledonia. Pacific Journalism Review, 18(1), 148-170.

Leveson, B. (2011). Leveson inquiry: Culture, practice and ethics of the press. Available at www.levesoninquiry.org.uk

NZ Law Commission (2011). NZLC IP27. The news media meets 'new media': Rights, responsibilities and regulation in the digital age. Available at www.lawcom.govt. nz/project/review-regulatory-gaps-and-new-media

Repúblika pledges to 'emerge from media shadows' (2012, September 13). Pacific Media Watch, No 8104. Retrieved on September 17, 2012, from www.pmc.aut. ac.nz/pacific-media-watch/fiji-rep-blika-manifesto-pledges-emerge-mediashadows-8104 